\title{
IAMJ
}

INTERNATIONAL

AYURVEDIC

MEDICAL JOURNAL

\section{AWAKENING ON BRAHMA MUHURTA AND ITS UTILITY FOR HEALTHY AND BLISSFUL LIFE IN CURRENT ERA - A REVIEW}

\author{
Jaybhaye Sulakshana ${ }^{1}$, Kendre Manchak ${ }^{2}$ \\ ${ }^{1}$ Professor, Department of Swasthavritta, ${ }^{2}$ Professor, Department of Kayachikitsa \\ S.G. Patel Ayurveda Hospital and Research Center, New Vallabha Vidya Nagar, Anand, Gujarat - 388121, India
}

Corresponding Author: brahmi29@gmail.com

\section{https://doi.org/10.46607/iamj4808102020}

(Published online: October 2020)

Open Access

(C) International Ayurvedic Medical Journal, India 2020

Article Received: 01/10/2020 - Peer Reviewed: 03/10/2020 - Accepted for Publication: 04/10/2020

\section{A) Check for updates}

\begin{abstract}
Brahma Muhurta is the second last Muhurta, two Muhurta (one hour thirty-six minutes) before sunrise. It is best for good practices like Yoga, Pranayam, Dhyana, Atmagyana, Parmatma gyana, Adhyayana etc. for ultimate achievement. Awakening on Brahma Muhurta for good practices contributes health in all aspects as well as longevity. Aim of this study is to review the Brahma Muhurta concept from Vedic period to present era and its need for healthy and blissful life in current era. For this study Veda, Upveda, Brahmnak, Vedang Jyotishya, Brihatsamhita, Kautilya Shastra and Yoga Darshana are overlooked. Online search is completed using various related key words. Collective knowledge is utilized wherever necessary. It is found that Brahma-Muhurta is very auspicious Muhurta for good practices. Our Maharishis have experienced this Muhurta for good practices as well as super consciousness and lived healthy, blissful long life. In present century, lifestyle is significantly changed which is creating lot of instability in physical, mental, spiritual and social health hence beginning of healthy lifestyle with awakening on Brahma- Muhurta for good practices is needed for healthy and blissful life.
\end{abstract}

Keyword: Brahma, Muhurta, Brahma-Muhurta, Health and longevity, Supreme time for Dhyana

\section{INTRODUCTION}

Due to sky-scraping materialistic developments human life is significantly changed. Late night duty, night duty, day night duties, late night parties, night bars, late night movies, late night television, late night 
chatting, infinite competition, never-ending requirements etc. disturbed the natural healthy scheduled life of human. Countless health facilities are indicators of unhealthy population. Humans are forgetting that health is fundamental requirement of their Dharma, Artha, Kama and Moksha which is aim of human life. ${ }^{[1]}$ Healthy lifestyle with each day beginning by awakening on Brahma Muhurta for good practices is basic requirement of health in all aspects.

Atharvaveda states that person who awake early in morning will be free from diseases. Bhagavadgeeta declared that person whose Ahara and Vihara is proper, activities as well as lifestyle is ideal, moreover follows early to bed and early to rise will be free from all miseries. Charaka Samhita illuminate that it is essential for a scholar to get up early in morning. Astanga Samgraha enlighten that after awakening early in morning, one should assure proper digestion of food consumed during last night. Bhavaprakasha mentioned the significance of pray to Parmatma after getting up on Brahma Muhurta. Online search confirms that Brahma Muhurta is best for various good practices like Yoga, Pranayam, Vyayam, Dhyan, Atma Gyana, Parmatam Gyana and religious efforts. Scientists noticed that rate of secretion of ACTH is more in early morning and low in evening which helps to withstand the stress and trauma in life ${ }^{[2]}$.

All relevant literatures were reviewed, online search was completed with different key words, relevant matter was collected, arranged in chronological order and review is prepared.

Brahma Muhurta is one hour thirty six minutes before sunrise and it is very auspicious Muhurta for various good practices like Yoga, Pranayam, Vyayam, Dhyan, Atmagyana, Parmatmagyana etc. which is needed for physical, mental, spiritual and social health as well as blissful life which is outcome of this study.

\section{Aim}

Aim of this study is to review the need of awakening on Brahama Muhurta and its utility for healthy and blissful life in current era.

\section{Methodology}

For this study Veda, Upveda, Brahmnak, Vedang Jyotishya, Brihatsamhita, Kautilya Shastra, and Yoga Darshana are overlooked. Online search is done using various related key words. Collective knowledge is utilized wherever necessary.

\section{What is Brahma Muhurta?}

Brahma is the creator; one of the three major gods. ${ }^{[3]}$ Brahma means knowledge. ${ }^{[4]}$ Muhurta is time period of approximate 48 minutes. ${ }^{[5]}$ Brahama Muhurta is supreme time period to establish a firm inner connection with the omnipresent divine Parmatma. It is best time to establish the rhythm of inner energy with rhythm of cosmos energy. It is most excellent time for Dhyana, Yoga, knowledge and initiation of any vital effort. In the way the planet is spinning and what is happening something very fundamental change somewhere between 4.04 to 5.24 A.M., this is called Brahma Muhurtam. ${ }^{[3]}$

In Rig-Veda Muhurta word is used twice. 'Shathapatha Brahmana' defines Muhurta as fifteenth part of the day. Furthermore, in Taittariya Brahmana 15 names of Muhurta of day and night have been given as Samjñ̄ānam, Vijñānam, Prajñ̄anam, Jānad, Abhijānat, Samkalpamānaì, Prakalpamānam, Upakalpamānam, Upaklptaì, Klptam, Śreyo, Vasīya, Āyat, Sambhütam and Bhūtam. In 'Vedang Jyotishya' part of Rig-Veda, it is specified that, a Muhurta is formed by 'two Nadika (Ghatika)' and a difference of 6 Muhurta or 12 Ghatika is observed among a longest and the shortest day. Even Manu and Chanakya has revealed the same meaning in their respective texts. Gradually the names of the Muhurtas shuffled and in the period of Varahamihira only the names of deities of 30 Muhurtas remains. It is specified in Brihatsamhita that if we perform some work on divinity of particular Nakshatra then success is assured. ${ }^{[6]}$ Ayurvedic literature firmly suggests that Brahma Muhurta is early morning specific time period for rising up. ${ }^{[7,8,9,10]}$ Arunadatta, Indu and Hemadri opine that when day and night are of equal time, each of it consists of fifteen Muhurtas. Hence, a Muhurta is of 48 minutes. Brahma-Muhurta begins at dawn; it is the penultimate Muhurta of night.

Table 1: showing name of Muhurta, time and quality ${ }^{[6]}$

\begin{tabular}{|l|l|l|l|}
\hline No. & Muhurta & $\begin{array}{l}\text { Correlate } \\
\text { Time of Day }\end{array}$ & Guna (Quality) \\
\hline 1 & Rudra & $\begin{array}{l}06: 00-06: 48 \\
\text { (sunrise) }\end{array}$ & Inauspicious \\
\hline 2 & $\bar{A} h i$ & $06: 48-07: 36$ & Inauspicious \\
\hline 3 & Mitra & $07: 36-08: 24$ & Auspicious \\
\hline 4 & Pit $\bar{r}$ & $08: 24-09: 12$ & Inauspicious \\
\hline 5 & Vasu & $09: 12-10: 00$ & Auspicious \\
\hline 6 & Vărāha & $10: 00-10: 48$ & Auspicious \\
\hline 7 & Viśvedevā & $10: 48-11: 36$ & Auspicious \\
\hline 8 & Vidhi & $11: 36-12: 24$ & $\begin{array}{l}\text { Auspicious - } \\
\text { except Monday }\end{array}$ \\
\hline
\end{tabular}




\begin{tabular}{|c|c|c|c|}
\hline & & & and Friday \\
\hline 9 & Sutamukhī & $12: 24-13: 12$ & Auspicious \\
\hline 10 & Puruhūta & $13: 12-14: 00$ & Inauspicious \\
\hline 11 & Vāhinī & $14: 00-14: 48$ & Inauspicious \\
\hline 12 & Naktanakarā & $14: 48-15: 36$ & Inauspicious \\
\hline 13 & Varuna & $15: 36-16: 24$ & Auspicious \\
\hline 14 & Aryaman & $16: 24-17: 12$ & $\begin{array}{l}\text { Auspicious - } \\
\text { except Sunday }\end{array}$ \\
\hline 15 & Bhaga & $17: 12-18: 00$ & Inauspicious \\
\hline 16 & Giriśa & $\begin{array}{l}\text { 18:00 - 18:48 } \\
\text { (sunset) }\end{array}$ & Inauspicious \\
\hline 17 & Ajapada & $18: 48-19: 36$ & Inauspicious \\
\hline 18 & Ahir-Budhnya & $19: 36-20: 24$ & Auspicious \\
\hline 19 & Pusya & $20: 24-21: 12$ & Auspicious \\
\hline 20 & Aśvini & $21: 12-22: 00$ & Auspicious \\
\hline 21 & Yama & $22: 00-22: 48$ & Inauspicious \\
\hline 22 & Agni & $22: 48-23: 36$ & Auspicious \\
\hline 23 & Vidhatr & $23: 36-24: 24$ & Auspicious \\
\hline 24 & Kanda & $24: 24-01: 12$ & Auspicious \\
\hline 25 & Aditi & $01: 12-02: 00$ & Auspicious \\
\hline 26 & Jiva/Amrta & $02: 00-02: 48$ & Very Auspicious \\
\hline 27 & Vișṇu & $02: 48-03: 36$ & Auspicious \\
\hline 28 & Dyumadgadyuti & $03: 36-04: 24$ & Auspicious \\
\hline 29 & Brahma & $04: 24-05: 12$ & Very Auspicious \\
\hline 30 & Samudram & $05: 12-06: 00$ & Auspicious \\
\hline
\end{tabular}

What should be done on Brahma Muhurta?

All ancient scriptures mentioned that one should pray for Ishvar on Brahma muhurta, Maharshi Angira coated to remember Hari after cleaning of hand and legs early in morning, Manu discussed to think about Dharma, Maharshi Charaka explained that it is important for a scholar to get up early in the morning for Veda and Samhita adhyayana. ${ }^{[11]}$ Vagbhat enlightened that awakening early in morning helps for preserving the health and longevity. ${ }^{[12]}$ According to Vriddha Vagbhat after awakening early in morning one should assure proper digestion of food taken during last night. ${ }^{[13]}$ Arundatta coated that it is the perfect time to achieve knowledge. Bhavaprakasah and Yogaratnakara mentioned to memorize Madhusudana at this time and advised to touch and see some auspicious substances like curd, Goghrita, Sarshapa, Bilwa, Gorochana, flower garland as well as look at himself in Ghrita for longevity. ${ }^{[14,15]}$ Online safari shows, it is time of Brahma and favorable for meditation of Brahma. It is most excellent time for initiation and process of Brahma Gyana, Atma Gyana, Parmatma Gyana, Yoga, Pranayam, Dhyana, Vyayam, Adhyayana etc. for their greatest achievement.

\section{Advantages of awakening on Brahma Muhurta}

Awakening early morning offer more time for good practices like Yoga, Pranayam, Dhyana, Atmagyana, Parmatma gyana, study etc. and award better spiritual, physical as well as psychological health. It reduces stress, improves intellect and provides blissful life. It helps to improve immunity at optimum level. It helps to synchronize with cosmos energy rhythm. In 2010, Christoph Randler, a biologist from Harvard University found that early risers are more proactive. ${ }^{[16]}$ Research conducted by Texas University noticed that students who consistently woke up early each day actually scored better test scores and overall grade points, in comparison to those who continues sleep during morning. ${ }^{[17]}$

\section{Disadvantages of late awakening}

Smrti Ratnavali mentioned that the people who sleeps at the time of Brahma Muhurta they loss their Punnya, they suffer ill health. After six A.M. Kapha predominance is seen. ${ }^{[18]}$ So people who get up in Kapha Kala tend to be dominated by Tamoguna throughout the day. Bowel movements tend to be sluggish under the influence of Kapha. Mind and body activities become sluggish owing to the influence of Kapha Dosha. After sunrise people awake and the materialistic mental radiations are emitted through their physical senses. The atmosphere is polluted. People will disturb each other dragging themselves to materialistic discussions. Fetid smell in mouth, constipation, indigestion, laziness, and many kinds of diseases arises just because of getting late in a day.

One should get more benefits of it by awakening at the time of early morning. Studies have shown morning people are often more positive, more optimistic and more likely to experience satisfaction in their lives. While several night owls are known for their creativity, they can also pay the price by becoming more likely to succumb to various health problems. ${ }^{[19]}$

\section{RESULT AND DISCUSSION}

Brihma Muhurta is time period of two Muhurta (one hour thirty-six minutes) before sunrise. Different opinions are observed regarding this time period of Brahma Muhurta. After proper study it can be accepted that Brahma Muhurta starts two Muhurta before sun rise and last for one Muhurta period. for example if sunrise is at 6 A.M. then it starts $48+48=96$ minutes before 6 A.M., that is, it starts at 4.24 A.M. and lasts till 5.12 A.M. Time of sunrise keeps 
changing within the range of 5.40 to 7 A.M. hence Brahma Muhurta starting time ranges from 4.04 to 5.24 A.M.

It is found that Brahma Muhurta is very auspicious Muhurta for various good practices. Parmatma Gyana and Atmagyana regarding efforts on this Muhurat improves optimum spiritual life quality. Yoga, Pranayam, Dhyan practices awards highest physical and mental health which is basic need for appropriate Dharma, Artha, Kama and Moksha as well as blissful life. Our Maharishis have experienced excellence of cosmos energy on Brahma Muhurta and established rhythm of inner energy with cosmos energy by various practices and lived healthy as well as blissful long life.

We know that atmosphere is made up of various layers. These layers are composed of Nitrogen, Oxygen, and Argon as well as other various energy constituents. They provide energy to the living beings. They transfer light from Sun to the Earth as well as reflect back to some extent. The molecules in the layers absorb energy and radiation. This radiation will heat the layers and the layers goes up and up by the end of a day. When the Moon reflects its cooling emissions, these layers will get cooled and comes down. At the time of Brahma Muhurta, these layers will settle down to the maximum and excellent energy level amplified. When we wake up at this time and proceeds to rhythm with this energy, our inner energy gets associated with cosmos energy. Hence Initiation of any vital effort on Brahma Muhurta becomes more fruitful due to association of our energy with cosmos energy.

Many problems that human beings are suffering is simply because they have lost that awareness as to how to be in synchronize with the many forces of cosmos energy. Human life is product of cosmos energy. He is not an individual existence. So, when he gets in synchronize, certain things will happen. Hence Yoga is to bring that synchronize so that his energy rhythm goes with the rhythm cosmos energy. If there is live seed and he awake at Brahma Muhurtam and sit for whatever that practice is, it bears maximum fruit.

In present century, lifestyle is significantly changed which is creating lot of instability in human energy. It is needed to synchronize the rhythm of inner energy with rhythm of excellent cosmos energy during Brahma Muhurta which is necessary for best immune energy. Quality immune energy is basic requirement for physical, mental, spiritual and social health as well as blissful life. Hence beginning of healthy lifestyle with awakening on Brahma- Muhurta for good practices is needed in present era.

\section{CONCLUSION}

Brahma Muhurta is approximate 48 minutes time period, one hour thirty-six minutes before sunrise. It is best time to synchronize our inner energy to excellent cosmos energy. It is very auspicious Muhurta for various good practices like Yoga, Pranayam, Dhyan, Atmagyana, Parmatmagyana, Adhyana for ultimate achievement etc. These practices help to synchronize with cosmos energy which provides best immune energy. Excellence of immune energy is basic need of quality physical, mental, spiritual and social health as well as blissful life which is basic need of human in present era.

\section{REFERENCES}

1. Agnivesha, Charaka, Dridhabala, Charaka Samhita, edited by Vaidya Yadavaji Trikamji Aacharya, 2nd edition, Chaukhamba Sanskrit Sansthan, Varanasi, 1990, Su. 1/15.

2. Scientific background of "Brahma Muhurta" Dr. Ranjith Kumar Shetty

3. http://en.wikipedia.org/wiki/ Brahma Muhurta.

4. Ashtangahrdyam of Vagbhata, edited with the Vidyotini Hindi commentary by Kaviraj Atridev Gupta, edited by Vaidya Yadunandana Upadhyaya, Chukhamba Prakashan, Varanasi, Edition: reprint 2011, Su. 2/1

5. https://en.wikipedia.org/wiki/Muhurta, http://en.wikipedia.org/wiki/Brahma Muhurta

6. Muhurta a concept to be amended as per modern times by Pandit Vijay Shrikrishna Jakatdar on https://pdfslide.net/documents/muhurtaa-revision.html

7. Ashtangahrdyam of Vagbhata, edited with the Vidyotini Hindi commentary by Kaviraj Atridev Gupta, edited by Vaidya Yadunandana Upadhyaya, Chukhamba Prakashan, Varanasi, Edition: reprint 2011, Su. 2/1

8. Ashtang Samgrah edited with Arthaprakashika Vyakhyaya by Vaidya Govardhansharma Changani, Chaukhamba Sanskrit Sansthan, Varanasi, 2005; Su. $3 / 3$

9. Bhavprakasha of Bhavmishra edited with the Vidyotini Hindi commentary by Brahmasankar Mishra \& Rupalalaji Vaisya, Part-I, 5/15-16, P.109

10. Yogaratnakar, with the Vidyotini Hindi commentary by Vaidya Lakshmipati shastri, Chukhamba prakashan, Varanasi, Nitya pravritti prakara 3-4, P.55 
11. Agnivesha, Charaka, Dridhabala, Charaka Samhita, edited by Vaidya Yadavaji Trikamji Aacharya, $2^{\text {nd }}$ edition, Chaukhamba Sanskrit Sansthan, Varanasi, 1990; Vimana sthana 8/7

12. Ashtangahrdyam of Vagbhata, edited with the Vidyotini Hindi commentary by Kaviraj Atridev Gupta, edited by Vaidya Yadunandana Upadhyaya, Chukhamba prakashan, Varanasi, Edition: reprint 2011, Su. 2/1

13. Ashtang Samgraha edited with Arthaprakashika Vyakhya by Vaidya Govardhan sharma Changani, Chaukhamba Sanskrit Sansthan, Varanasi, 2005; $\mathrm{Su} .3 / 3$

14. Bhavprakasha of Bhavmishra edited with the Vidyotini Hindi commentary by Brahmasankar Mishra \& Rupalalaji Vaisya, Part-I, 5/15-16, P.109

15. Yogaratnakar, with the Vidyotini Hindi commentary by Vaidya Lakshmipati shastri, Chukhamba prakashan, Varanasi, Nitya pravritti prakara 3-4, P.55

16. https://onlinelibrary.wiley.com/doi/abs/10.1111/j.15591816.2009.00549.x, Defend Your Research: The Early Bird Really Does Get the Worm, by Christoph Randler, July-August 2010

17. www.healthambition.com/benefits-of-waking-up-early.

18. Ashtangahrdyam of Vagbhata, edited with the Vidyotini Hindi commentary by Kaviraj Atridev Gupta, edited by Vaidya Yadunandana Upadhyaya, Chukhamba Prakashan, Varanasi, Edition: reprint 2011, Su.1/8

19. Proactive People Are Morning People, December 2009, Journal of Applied Social Psychology 39(12):2787-2797 DOI: 10.1111/ j.1559-1816.2009. 00549.x

\section{Source of Support: Nil Conflict of Interest: None Declared}

How to cite this URL: Jaybhaye Sulakshana Kendre Manchak: Awakening On Brahma Muhurta And Its Utility For Healthy And Blissful Life In Current Era - A Re-view. International Ayurvedic Medical Journal \{online\} 2020 \{cited October, 2020 $\quad$ Available from: http://www.iamj.in/posts/images/upload/4866_4870.pdf 